\title{
Holistic Practice of Fiqh Al-Muamalat: Halal Accountability of Islamic Microfinance Institutions
}

\author{
Helmi Muhammad \\ Economy and Business Faculty, Universitas Islam Raden Rahmat, Jl. Raya Mojosari No. 2, \\ Kepanjen, Malang 65163, Indonesia
}

Correspondence should be addressed to Helmi Muhammad: helmimuhammad@uniramalang.ac.id

Cite this: Nusantara Halal J. 2020, Vol. 1 No. 1 pp. 22-31 (Article) | Received 1 July 2020 | Revised 4 August 2020 | Accepted 6 August 2020 | Published 21 August 2020 |

http://dx.doi.org/10.17977/um060.2020v1p022-031

\begin{abstract}
This study aims to discover the practice of fiqh al-muamalat (Islamic law of transaction following Islamic fiqh) as a sharia-compliant, primarily the halal accountability of Islamic microfinance institutions Baitul Maal wa Tamwil (BMT) UGT Sidogiri Indonesia. This research used a descriptive, explanatory design with a holistic single-case design focus and was conducted from 2019 to 2020. For the data collection process, in-depth interviews were conducted with the informants. The data were analyzed using an interactive model consisting of data reduction, data presentation, and conclusion drawing. The results exhibit that Islamic sharia, faith (iman), and good deeds (ihsan) act as the foundation of fiqh al-muamalat practices. The compliant toward sharia does not only represent the operational system, but it becomes a working culture through worship practices. Besides, this research also discovers that the fiqh almuamalat was practiced to fulfill the halal responsibility.
\end{abstract}

Keywords: fiqh al-muamalat, Islamic micro finance, Halal accountability, sharia compliance.

\section{Introduction}

Islamic financial system has gained world communities', the Muslim or non-Muslim, recognition as a unique and universal system organizing goods and services [1]. The operational success of Islamic financial institutions has proven that a new financial intermediation model can survive, as well as excel conventional model [2]. Besides, it is also perceived as an ethical project [3]. That is because the Islamic financial system is based on sharia principles that do not discriminate religious and other life aspects [4]. In other words, Islamic law encompasses all human behavioral aspects, including commercial business transactions [5]. Further, in the Islamic economy, humans are required to perform productive activities that bring positive 
impacts for others while prohibits destructive activities related to forbidden matter [4]. This comprehensive Islamic sharia becomes the fundamental of Islamic financial system acknowledged to bring ethical changes globally. Besides focusing on interest (riba) and other disadvantageous features in the process, the Islamic financial system also runs based on partnership patterns, which is perceived to be fairer.

As a unique financial system, Islamic financial institutions involve five religious components that shifted its identity and distinguished it from conventional financial institutions. Those components include interest prohibition, halal, haram and speculative (gharar) or gambling (maysir) consideration; zakat (the prescribed purifying alms) practice; and sharia board existence [6,7]. Its purpose is to realize a fair society that avoids exploitation and enforce collaboration and kinship principles. These noble purposes can be accomplished once sharia law is strictly adopted [8]. In another perspective, the sharia purpose of the Islamic financial system is to guide human from homoeconomicus manner that merely leads to profit attainment, to homoislamicus behavior based on ethics and morals, as well as avoiding consumerism and greed [9-11].

These experts' statements indicate that to build an ethical Islamic financial system, Islamic financial institutions have to pay attention to various aspects of Islamic law. First, the laws for products circulated in the market should be following sharia (al-muamalah al-madiyah). Second, the transaction process and the goals have to be in line with sharia (al-muamalah al-adabiyah and al-maqashid al-shariah). The sharia compliance in those aspects will ensure that every transaction is halal. Contrarily, a little deviation from sharia will affect the illegitimate (haram) status of the financial transaction. This Islamic sharia teaches its followers that the attainment of halal fortunes through ethical ways is preferred than the fortunes quantity.

The problems lay in the ways that Islamic financial institutions assure that every transaction is halal and free from unethical means. This problem appears as a response from a study that declares Islamic financial products are complicated, not popular, and hard to be comprehended even by the Islamic financial institutions' staffs [12]. Also, the global financial crisis generated from unethical business practices, such as manipulation, non-transparent information, the presence of incentive structure that encourage taking high risk and collusion between financial institutions and other institutions, should not happen within Islamic financial institutions [13]. Results of studies $[12,13]$ reveal that fiqh al-muamalat (transaction based on Islamic sharia) understanding from the Islamic financial institutions' management and staff are still low. Consequently, it affects the opportunities to violate the existing sharia laws and the halal level of the financial transaction. Therefore, specific regulations that organize sharia compliance within the Islamic financial institutions and sharia-based cooperative are required through the existence of the Sharia Board. This Sharia Board holds a critical role to supervise and ensure the operation of Islamic financial institutions is in line with the proper sharia ethics and fiqh al-muamalat practice to produce the halal business transaction, and to carry out other halal education.

Current studies on sharia compliance only aim to discover the demand of general sharia compliance within sharia banks [14,15], the definition of Sharia compliance in the philosophical perspective [16], the history and features of Islamic business law adopted in financial institutions [17] or the business practices based on sharia related to the company financial 
performance [18]. Those research indicate that sharia compliance is only perceived as the needs of business operational in Islamic financial institutions. However, the studies have not investigated the sharia compliance practices (fiqh al-muamalat practice) in an Islamic financial institution that transform into a working culture.

The fiqh al-muamalat practices should not only be manifested in the companies' standard regulation system but should also be also performed daily that even become habit and working culture. The acceptable and ethical fiqh al-muamalat practices assure halal business transactions. This correlation is close since, in realizing halal business transactions, the fiqh almuamalat should be performed holistically rather than partially.

This research fills that gap by investigating the fiqh al-muamalat practices to ensure halal and ethical transactions in Islamic boarding school (pesantren) based Sharia microfinance institution. This research case was obtained from BMT UGT Sidogiri as one of the biggest sharia cooperatives that becomes a reference in Indonesia, with more than 3 trillion total assets and more than 21.000 members. Uniquely, BMT UGT Sidogiri is operated by the alumni of Sidogiri Islamic boarding school, Indonesia, with no specific background in the economy or modern businesses. This study on fiqh al-muamalat practices is essential since it becomes part of the working culture that assures halal and ethical business transactions. Besides, this research also helps to evade the issue of sharia cooperative business practices that are similar to the conventional cooperative. Comprehension of fiqh al-muamalat becomes the fundamental of business practices to proper run properly if there is awareness from every stakeholder through the Sharia Board role.

\section{Methodology}

This qualitative study used descriptive, explanatory design [19] and was conducted from 2019 to 2020 with a holistic single-case design [20] in BMT UGT Sidogiri Indonesia. The informants in this study were the head of management board, sharia board, head of the branch, head of risk management board, and the staff. The data collection was carried out through an in-depth interview [20] with several informants. The interview results were recorded and transcribed to be the source of discussion. The data analysis was completed using an interactive model consisting of data reduction, data presentation. And conclusion drawing [21]. To maintain the research quality, the validity check, data comparison, and data verification in this research were performed using data triangulation, as well as observer triangulation [22].

\section{Discussion}

Generally, the discussion in this study presents fiqh al-muamalat practices in BMT UGT Sidogiri as the business fundamental to generate a halal transaction. That covers the basic foundation of fiqh al-muamalat practices involving the foundation of Islamic sharia, faith (iman), and good deeds (ihsan). Besides, the model of fiqh al-muamalat practice that include the law of goods (almuamalah al-madiyah) and the law of transaction (al-muamalah al-adabiyah) are also discussed. The discussion is concluded with halal accountability as the effect of fiqh al-muamalat practices. 


\section{Basic Foundation of Fiqh Al-Muamalat (Sharia Compliance)}

\section{Foundation of Islamic Sharia}

Sharia means Islamic teaching. The implementation of Islam through sharia shapes Muslim behavior and become the energy in halal business practices. The research results discover that proper and acceptable practice of fiqh al-muamalat starts from the implementation of sharia. The informants mentioned that sharia is a set of norms, values, and laws that regulate Islam ways of life. The sharia practice in BMT UGT Sidogiri is manifested in the practice of Duha prayer, Al-Quran recitation before the working hour, congregational Zuhr prayer, congregational Asr prayer, congregational prayer after the working hour and weekly religious studies. The commitment toward religion through the implementation of sharia builds work ethics, such as honest, virtuous, responsible, and not careless to the assigned task. Besides, it also helps people to create proper self-discipline. It is a discipline that appears from self-awareness and selfcommand. Acceptable self-discipline affects group discipline. In other words, the group produces a maximum result, once each of its members contribute a pertinent responsibility and right. The informants' statements are in line with the results of a previous study that finds sharia practices bring social effects and accelerates self-actualization [23].

Therefore, these Islamic sharia practices evolve into working culture in business practices, even if it is not manifested in the company's regulation. This sharia practice is the gate of proper fiqh al-muamalat implementation. The informants also acknowledge that sharia compliance within the businesses carries various issues, such as the management seriousness, the staffs' understanding and awareness of sharia. Through the practice of praying, reciting Quran, congregational prayer, and religious study that becomes the working culture, the Islamic business ethic and intelligence can be improved. This effort can be the answer to the poor [15]. Besides, it also eliminates the obstacles of sharia compliance, which have been investigated [14].

\section{Foundation of Faith (Iman)}

Faith (Iman) to Allah is the fundamental base for various activities, including the behavior and action as a form of worship [24]. Also, the iman to Allah becomes the primary foundation that affects all parts of life, involving the soul, body, behavior, not only perceived as worship procedure but also seen as a virtue practice [25]. The research results exhibit that the implementation of Islamic sharia in the business culture, such as prayer, congregational praying, Quran recitation, establish ethical behavior, as well as nourish the faith. The informants said that iman should be sustained since it can fluctuate. Thus, the practice of Islamic sharia in business culture is critical. The essence of Islamic sharia in every business transaction can be sensed in the soul with a solid faith in Allah.

In addition, the informant also stated that the fiqh al-muamalat in Islamic financial institutions remains in the operating system level and has not achieved its core. It is proven by many stakeholders or the management of sharia financial institution who are non-Muslim. Indeed, everyone can study fiqh al-muamalat, even the non-Muslim, but the ways that a person attains its core value can be burdensome if the person has no iman to Allah. Therefore, other than transferring the culture of Islamic sharia within the business, the Islamic financial institutions 
should begin with recruiting Islamic boarding school alumni for at least $90 \%$ of staff. The Islamic educational background eases the correct and proper comprehension of fiqh al-muamalat.

Besides, iman to Allah and its implementation in business activities benefit humans in both life and after-life. This concept is different from conventional business ethics that emphasizes the worldly material profits. Faith generates two perceptions for the businessman. First, that production factor is Allah's creation that also belongs to Him. Thus, human ownership is exceptionally relative and limited. Therefore, the willingness to pursue halal wealth and avoid the prohibited (haram) goods become compulsory through the acceptable comprehension of fiqh al-muamalat. Second, humans are created to worship Allah. Thus, human attitude in the business context is for worshipping Allah. In other words, the business should be operated following the Islamic sharia. The informants' ideas support the result of the previous study stated that all fortunes belong to Allah and have to be used in His ways [26].

\section{Foundation of Good Deeds (Ihsan)}

The comprehension of fiqh al-muamalat and sharia compliance in Islamic financial institutions based on sharia practices and faith to Allah produce ethical behavior (Ihsan) for the staff and the institution. This idea was expressed by the informants. Philosophically, ihsan represents good deeds that benefit others with no retribution [27]. As the base of fiqh al-muamalat, ihsan purpose is to maximize the profit, as in pure capitalism, and also consider fairness. The moral and ethical values in the Islam perspective is known as akhlak (righteous) $[28,29]$ that leads to divine awareness or known as piety (taqwa) in another view [30].

The informants stated that fiqh al-muamalat and sharia compliance lead to ethical behavior, not only to other people and the environment but also to Allah. In other words, the implementation of fiqh al-muamalat demonstrates sharia compliance and being ethical to Allah. That is illustrated in the halal business transaction using ethical means that does not breach the Islamic sharia. Thus, the foundation of Islamic Sharia, iman, and ihsan are inseparable. This perspective is different from the idea of a previous study that establishes a multi-level framework of Islamic ethics [31]. Also, the informants stated that the business principles in the company's operational level are free from an unethical transaction that only pursue profits. This fundamental becomes the filter of halal products produces by BMT UGT Sidogiri. At the management level, the institution and the staffs are socially responsible for managing and distributing alms (zakat), conduct charities and philanthropic activities that positively contribute to develop society, uphold the employees' rights and be environmentally friendly, as the business ethics.

\section{The Practice of Fiqh AI-Muamalat and Halal Accountability}

Muamalat (Islamic law) regulates social interactions with the logical consequence of other people's rights being fulfilled. Fiqh al-muamalat represents material and its advantages for people through contract and commitment framed in sharia [32]. Islamic law has two aspects, the law of goods (al-muamalah al-madiyah) and the law of transaction (al-muamalah al-adabiyah). The Islamic law of goods is the muamalat related to products since its objects are halal (permitted) goods, haram (forbidden) goods, syubat (in between halal and haram), harmful (mudharat) goods, and beneficial (maslahat) goods among people that being bought and sold. On 
the other hand, the Islamic law of transaction covers the muamalat perceived from the procedure of the transaction of goods, with rights and responsibilities as the enforcer, such as honesty, envy, jealousy, lie, and resentment [33]. Other than those, Islamic law also has two aspects, subjective and objective [34]. The objective element is associated with the facilities and utilization of resources to gain the expected result. While, the subjective aspect is referred explicitly to Muslim's subjectivity in business, different from non-Muslim. For a Muslim, the social transaction in the material world is still correlated to transcendental values and should not use financial-material standards only. Contrarily, non-Muslim may recognize this interaction as a universal material relation that has no effect from transcendent values.

The findings show that the fiqh al-muamalat practices in BMT UGT Sidogiri are not only profitoriented but primarily aim to achieve authentic happiness. The implementation of Islamic law considers the material (al-madiyah), as well as emphasizes the process and ethics (al-adabiyah), such as giving a recommendation [33,34], so that the result does not breach Islamic sharia. The management team members mostly have a religious educational background from the Islamic boarding school to understand the importance of fiqh al-muamalat practices in business transactions. They accentuate that business transactions and business results should improve their worship. This phenomenon becomes unique since they have learned fiqh al-muamalat in the Islamic boarding school; thus, the practices become their experience.

The features of fiqh al-muamalat practices in BMT UGT Sidogiri are based on general principles. Other than based on the Quran and Sunna to attain Allah's blessing, Islamic law is also dynamic and open for ijtihad (individual interpretation), following the dynamic social problem in society. Following the Minister of Cooperative Regulation No. 16/Per/M.KUKM/IX/2015 and bank of Indonesia Regulation No: 7/46/PBI/2005 that every contract sharia financial institutions have to follow the fatwa of National Sharia Board-Indonesian Council of Ulema (DSN_MUI). Therefore, every contract application for products from BMT UGT Sidogiri also refers to DSN-MUI's fatwa. Besides, the results of a study conducted by Sharia Regulatory Body of BMT UGT Sidogiri in integrating DSN-MUI's fatwas and classical Islamic books are documented in a book entitled "Book of Sharia Guidelines from Madzahib Al-Arba'ah: Theory and Practice in Financing Product." Their products include mudharabah, murabaha, ijarah, and istisna' contracts. Besides, it also has other solutive and applicative contracts to fulfill society's demand to avoid interest, such as kafalah, rahn, and bai' al wafa contracts.

Additionally, the informants also explained that the proper practice of fiqh al-muamalat produces ethical business that follows sharia. This statement support results of the previous study that find Islam prohibits someone from working recklessly and use every dreadful means, such as gambling (maysir), fraud (gharar), interest (riba), and so forth, while demands to consider the moral responsibility [35]. Islam provides a line between what is permitted (halal) and prohibited (haram). Gambling (maysir) covers every aspect within the betting [6]. While, fraud (gharar) represents uncertainty [36]. On the other hand, interest (riba) covers the increases required by the lender to the borrower, since the borrower exceed the designated due date [6]. This interest has been declared as haram by all clerics, not only the Muslim clerics but also clerics from other Abrahamic religions. 
The practice of fiqh al-muamalat in BMT UGT Sidogiri through the compliant toward DSN_MUI fatwas and ijtihad from four madhhabs that produces product transaction contract assures the halal status though transaction that follows Islamic values that represent the virtue of religion and sincerity to attain Allah blessing. The valid contract and halal product demonstrate proper sharia principle. Implementing an acceptable sharia principle means sincerely worshipping Allah, which also exhibit ethical means to Allah. In short, the foundation of Islam, iman, and ihsan are integrated within the practice of fiqh al-muamalat. The practice of fiqh al-muamalat in MBT UGT Sidogiri is illustrated in Fig. 1.

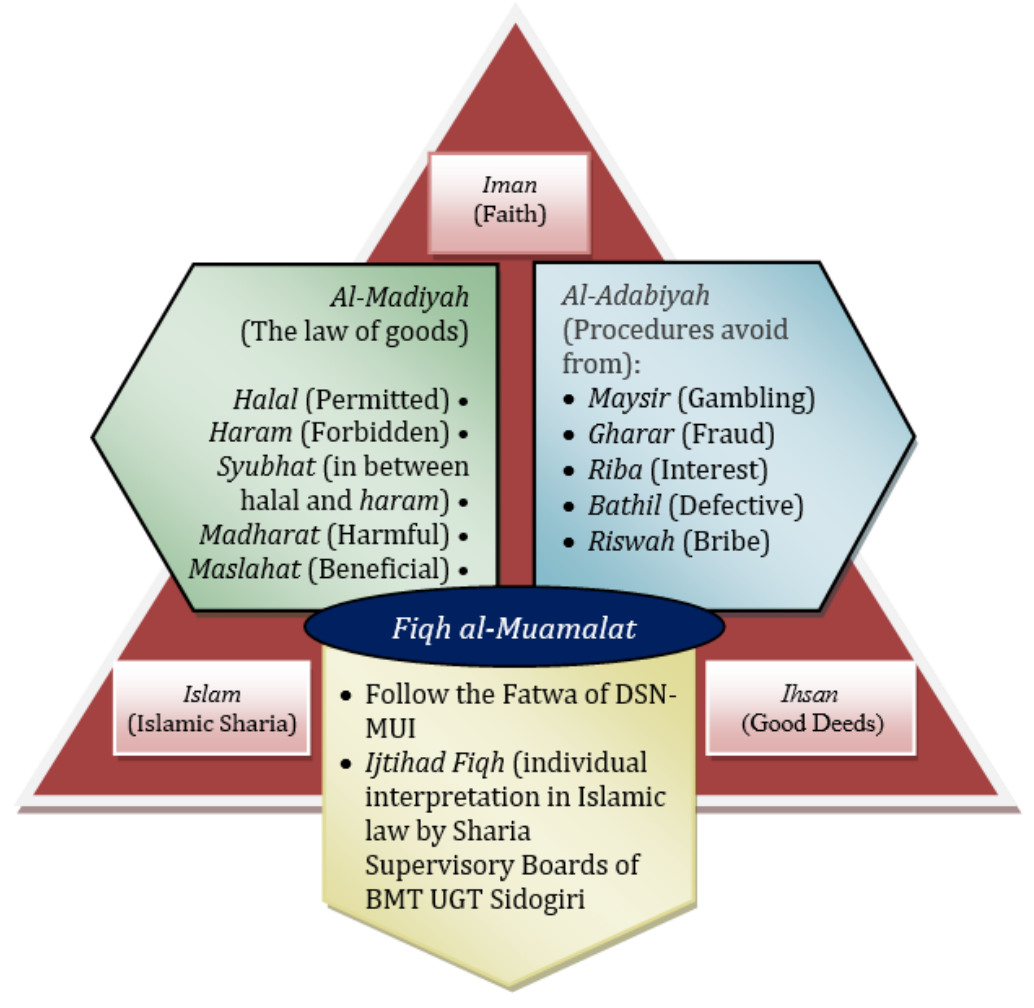

Figure 1. Holistic Practice of Fiqh Al-Muamalat Practices

The fiqh al-muamalat practice in BMT UGT Sidogiri purpose is to produce halal products based on Islamic sharia. This is implemented to give education and training on creating contracts, specifically for all heads of branches, as the decision-maker of transaction contracts in their area. Education and training are also provided for the staff. That education and training aim to achieve a comprehensive understanding of ethical business transactions based on sharia, as the halal liability. An in-depth understanding of fiqh al-muamalat practiced in the business assures three levels of halal, namely halal product, halal assurance of the product, and halal assurance of the business. The halal product means that the products of Sharia microfinance institutions are halal, free of interest, riba, or other prohibited features. The halal assurance of the product indicates the halal liability due to the sharia compliance through the proper and ethical practice of fiqh al-muamalat. The halal assurance of the business signifies the halal liability from the institution's perspective because it follows the standards set by DSN-MUI and sharia compliance.

The success of fiqh al-muamalat in ensuring the halal status as the business accountability of BMT UGT Sidogiri can be appropriately implemented by integrating the sharia compliance as the 
operating system and sharia practices as the culture. The accomplishment of integrating the functional system and culture is based on a similar holistic perspective toward sharia, starting from the Islamic boarding school education. The practice of fiqh al-muamalat with halal orientation demonstrates the institution's excellent image to avoid the issue of the similar transaction between sharia and conventional financial transaction. Also, it is part of a strategy to promote and label sharia financial institutions as halal financial institutions. This new phenomenon urges the halal label and halal transfer domain in business, as stated in the result of previous research [37]. Halal liability through the holistic practice of fiqh al-muamalat in BMT UGT Sidogiri produces various levels of halal, as presented in Table 1.

Table 1. Various-level Halal Accountability

\begin{tabular}{lll}
\hline Source & Halal Level & Definition \\
$\begin{array}{l}\text { The holistic } \\
\text { practice of fiqh } \\
\text { al-muamalat }\end{array}$ & Halal Business & $\begin{array}{l}\text { It covers the entire strategy of sharia financial } \\
\text { institutions in ensuring Halal business through } \\
\text { compliance with DSN-MUI standards. }\end{array}$ \\
& $\begin{array}{l}\text { Halal Product } \\
\text { Liability }\end{array}$ & $\begin{array}{l}\text { It covers the products of sharia financial institutions } \\
\text { follow the halal standard (such as sharia investment). }\end{array}$ \\
& Halal Product & $\begin{array}{l}\text { It represents the products of sharia financial institution } \\
\text { are halal from the law of goods perspective (free of } \\
\text { interest, riba, and defect). }\end{array}$ \\
& & \\
&
\end{tabular}

\section{Conclusions}

Islamic financial system adopted in Islamic financial institutions is unique, acknowledged by people around the world, and perceived to excel in the conventional financial system. The basic reason for that is because the Islamic financial system follows universal and ethical Islamic sharia. The remarkable feature of Islamic sharia should be in line with businessman sharia compliance trough the proper and ethical practice of fiqh al-muamalat. This phenomenon can be found in BMT UGT Sidogiri through the practice of fiqh al-muamalat in its halal framework. The practice of fiqh al-muamalat is properly and ethically implemented through intensive learning by the Sharia Board, along with the management team. Besides, there is also awareness of comprehensively implementing Islamic sharia through the continual religious ritual that shapes the working culture. The sharia compliance through the fiqh al-muamalat practices is not only perceived as the technical operation of sharia financial institution but also as the working culture. The integration of these two functions becomes the key to success in the fiqh almuamalat practices in BMT UGT Sidogiri and can be the reference for the Islamic financial institution. The appropriate and ethical practice of fiqh al-muamalat has a noble orientation as halal liability for a halal product, halal product accountability, and halal business accountability.

\section{References}

[1] H. Visser, Islamic finance: Principles and practice, Third edit. Northampton: Edward Elgar Publishing, 2019.

[2] M. Iqbal, "Islamic finance: An attractive new way of financial intermediation," Int. J. Bank. Financ., vol. 10, no. 2, pp. 1-24, 2020.

[3] R. Calder, "Sharī'ah-compliant or Sharīah-based? The Changing Ethical Discourse of Islamic Finance," Arab Law Q., vol. 1, no. aop, pp. 1-24, 2020.

[4] M. Hussain, A. Shahmoradi, and R. Turk, "An overview of Islamic finance," J. Int. Commer. Econ. Policy, vol. 7, no. 01, p. 1650003, 2016.

[5] N. H. Foster, "Islamic commercial law: An overview (I)," Indret Rev. Para El Análisis Del Derecho, vol. 4, no. 2006, pp. 1-14, 2006. 
[6] M. A. El-Gamal, Islamic finance: Law, economics, and practice. Cambridge University Press, 2006.

[7] M. K. Lewis and L. M. Algaoud, Islamic banking. Edward Elgar Publishing, 2001.

[8] Z. Iqbal and A. Mirakhor, An introduction to Islamic finance: Theory and practice, 2nd ed., vol. 687. Singapore: John Wiley \& Sons, 2011.

[9] D. B. Audretsch, W. Boente, and J. P. Tamvada, "Religion and entrepreneurship," Vol, 2007.

[10] A. A. Gümüsay, "Entrepreneurship from an Islamic perspective," J. Bus. Ethics, vol. 130, no. 1, pp. 199-208, 2015.

[11] M. A. Haneef, Contemporary Islamic economic thought: A selected comparative analysis. Kuala Lumpur: Alhoda UK, 1995.

[12] H. D. Seibel, "Islamic microfinance in Indonesia: The challenge of institutional diversity, regulation, and supervision,” SOJOURNJ. Soc. Issues Southeast Asia, vol. 23, no. 1, pp. 86-103, 2008.

[13] R. N. Kayed and M. K. Hassan, "The global financial crisis and Islamic finance," Thunderbird Int. Bus. Rev., vol. 53, no. 5, pp. 551-564, 2011.

[14] M. H. Abbas and H. Ali, "An empirical study of shari'ah compliance in Islamic banks of pakistan," J. Islam. Financ., vol. 8, no. 2, pp. 21-30, 2019.

[15] H. Ullah, "Shari'ah compliance in Islamic banking," Int. J. Islam. Middle East. Financ. Manag., vol. 7, no. 2, pp. 182-199, 2014.

[16] M. A. Laldin and H. Furqani, "Innovation versus replication: some notes on the approaches in defining shariah compliance in Islamic finance," Al-Jami'ah J. Islam. Stud., vol. 54, no. 2, pp. 249-272, 2016.

[17] H. Ahmed, "Islamic law, adaptability and financial development," Islam. Econ. Stud., vol. 13, no. 2, pp. 79-101, 2006.

[18] S. Pepis and P. de Jong, "Effects of shariah-compliant business practices on long-term financial performance," Pacific-Basin Financ. J., vol. 53, no. 2019, pp. 254-267, 2019.

[19] P. J. Brink and M. J. Wood, Advanced design in nursing research, Second edi. Barcelona: Sage, 1998.

[20] R. K. Yin, Case study research and applications: Design and methods. Sage publications, 2017.

[21] M. B. Miles, A. M. Huberman, and J. Saldaña, "Qualitative data analysis: A methods sourcebook. 3rd." Thousand Oaks, CA: Sage, 2014.

[22] M. Q. Patton, How to use qualitative methods in evaluation, no. 4. Sage, 1987.

[23] A. Al-Krenawi and J. R. Graham, "Islamic theology and prayer: Relevance for social work practice," Int. Soc. Work, vol. 43, no. 3, pp. 289-304, 2000.

[24] F. Grine, D. Fares, and A. Meguellati, "Islamic spirituality and entrepreneurship: A case study of women entrepreneurs in Malaysia," J. Happiness Well-Being, vol. 3, no. 1, pp. 41-56, 2015.

[25] G. Rice, "Islamic ethics and the implications for business," J. Bus. ethics, vol. 18, no. 4, pp. 345358, 1999.

[26] R. I. Beekun and J. A. Badawi, "Balancing ethical responsibility among multiple organizational stakeholders: The Islamic perspective,” J. Bus. ethics, vol. 60, no. 2, pp. 131-145, 2005.

[27] W. El Garah, R. I. Beekun, A. Habisch, G. Lenssen, and C. L. Adaui, "Character centered leadership: Muhammad (p) as an ethical role model for CEOs," J. Manag. Dev., vol. 31, no. 10, 2012.

[28] M. U. Chapra, S. Khan, and A. Al Shaikh-Ali, The Islamic vision of development in the light of maqasid al-Shariah, vol. 15. Iiit, 2008.

[29] S. N. H. Naqvi, "Islam, economics, and society (RLE politics of Islam)." Routledge, London, New York, 2013.

[30] A. W. Dusuki, "What does Islam say about corporate social responsibility," Rev. Islam. Econ., vol. 12, no. 1, pp. 5-28, 2008.

[31] W. El Garah et al., "Toward applied Islamic business ethics: responsible halal business," $J$. Manag. Dev., vol. 31, no. 10, pp. 1090-1100, 2012.

[32] M. U. Syubir, “al-Muamalat al Maliyah al-mu'ashirah li al Fiqh al Islami," Yordan Dar al-Nafais $H$, vol. 1418.

[33] A. Al-Fikri, “Al Muamalah Al Maliyah wa Al Adabiyah.” Darul Fikr, Beirut.

[34] M. B. Shadr, Iqtishoduna. Libanon: Dar Taaruf, 1991.

[35] A. Sachedina, The issue of Riba in Islamic faith and law. 2001.

[36] A. R. A. Haqqi, The philosophy of Islamic law of transactions. Univision Press, 1999.

[37] J. A. Wilson, "The halal phenomenon: an extension or a new paradigm?," Soc. Bus., vol. 4, no. 3, pp. 255-271, 2014.

\section{Corresponding author biography}

Helmi Muhammad works at the Faculty of Economics and Business, Universitas Islam Raden Rahmat, Indonesia. He received his Ph.D. in management science from Universitas Brawijaya, 
Indonesia, in 2019. His research interests include Islamic economics, Islamic finance, management, and business. He also becomes a business practitioner and chairman of the sharia supervisory board at the Bumi Meranti Wangi Islamic microfinance institution, Malang, Indonesia. 